\title{
TANGGUNG JAWAB NOTARIS DAN KEPASTIAN HUKUM BAGI KREDITUR AKIBAT LALAI DALAM PENDAFTARAN FIDUSIA ONLINE
}

\author{
Lirianna Nurtanio Jonatan, Gunawan Djajaputra \\ Universitas Tarumanagara (UNTAR) Jakarta, Indonesia \\ Email: luberberkat08@gmail.com,gunawand@fh.untar.ac.id
}

\begin{abstract}
Abstrak
Notaris sebagai pejabat umum memiliki tugas dan kewenangan yang utama adalah dalam hal pembuatan akta autentik termasuk didalamnya adalah pembuatan akta autentik perjanjian jaminan fidusia yang dilakukan antara kreditur dengan dan debitur dalam suatu perjanjian pembiayaan konsumen. Penelitian ini bertujuan untuk memaparkan pertanggungjawaban notaris kepada penerima fidusia dalam melakukan proses pendaftaran fidusia online dengan faktor-faktor pendukung dan penghambat dalam proses pendaftaran fidusia online. Penulisan ini dilakukan berdasarkan penulisan hukum normatif dan untuk selanjutnya dapat dianalisis dengan melakukan pendekatan deskriptif analitis dengan menggunakan tata cara atau metode pendekatan yuridis normatif yang mempergunakan beberapa sumber bahan hukum sekunder untuk membuat analisis dengan berbagai peraturan dalam perundangundangan di bidang hukum notaris, dan peraturan mengenai tata cara pendaftaran fidusia oleh notaris, buku-buku yang berkaitan dengan jaminan fidusia. Hasil penelitian yang didapat menunjukkan bahwa Objek Jaminan Fidusia online harus diterima dengan benar benar oleh notaris secara sangat berhati hati karena menjadi tanggung jawab notaris lebih besar, ruangan input dan penyimpanan semua dokumen pendukung harus dilakukan secara khusus diperhatikan, pelaksanaan dalam menginput data harus dengan benar-benar diperhatikan dengan dokumen yang disimpan. Kejujuran notaris sangat dibutuhkan dalam hal ini, agar jangan sampai timbul permasalahan yang dapat bertentangan dengan peraturan dan perundangundangan yang telah berlaku. Oleh karena itu maka notaris harus menjauhkan diri dari berbagai hal-hal yang mengandung, akal-akalan, penyembunyian data atau kenyataan, kecurangan, pelanggaran kepercayaan, penyesatan, dan pengelakan peraturan serta harus menjauhkan diri dari hal-hal yang akan mengarah kepada kejahatan korporasi.
\end{abstract}

Kata Kunci: notaris; pendaftaran online; fidusia online

\section{Abstract}

Notary public officials have the main duties and kinks in terms of making autentikk deed in it is true the creation of an authentic deed of fiduciary safe agreement in which creditors with and debtors in a consumer financing. This study is inspiring for regions per expert in looking at fiduciary actors in the online fiduciary registration process with supporting factors and inhibitions in online fiduciary registration. This writing is done away from normative legal writing and to be analyzed with an 
analytical descriptive approach by means of normative juridical ordinances or methods in which the word amanukan several sources of legal material for analysis with regulations in the field of notary law, and regulations on the procedure of registration of fiduciary ordinances by notaries, books related to the results of research that magnitude shows, Fiduciary Safe Objects online must be received correctly correctly by the notary so be careful and the notary responsibility is greater, there input and storage of all supporting documents must be dience, in input data should be actually asked with the documents that tedu. Notary honesty is very easy in this case, so that it arises no one is delivered with the prevailing laws and regulations. Therefore, the notary must be far from it from far-away things which, common sense, data concealment or problems, subdistricts, sure violations, misdirection, and evasion of regulations and and and away from things that will be the main company.

Keywords: notary; online registration; online fiduciary

\section{Pendahuluan}

Notaris sebagai pejabat umum memiliki tugas dan kewenangan yang utama adalah dalam hal pembuatan akta autentik termasuk didalamnya adalah pembuatan akta autentik perjanjian jaminan fidusia yang dilakukan antara kreditur dengan dan debitur dalam suatu perjanjian pembiayaan konsumen. Pelaksanaan pemberian kredit kendaraan bermotor oleh perusahaan pembiayaan selaku kreditor kepada para debitornya dilakukan dengan membuat suatu perjanjian pembiayaan konsumen dan juga diikuti oleh perjanjian jaminan fidusia, dimana kendaraan bermotor yang dibeli oleh debitor tersebut diikat dengan jaminan fidusia sebagai jaminan pelunasan hutang debitor tersebut kepada kreditor apabila debitor wanprestasi atas pelunasan hutang-hutangnya kepada kreditor (Octavianus, 2018). Seiring dengan harapan dan tuntutan seluruh warga negara tentang peningkatan pelayanan publik. Sebagai konsekuensinya, pemerintah harus meningkatkan kinerja dalam fungsi pelayanan publik agar lebih efektif, efisien, dan transparan demi terwujudnya tata kelola pemerintahan yang baik (good governance). Penelitian ini dimaksudkan untuk melihat sejauh mana notaris memperhatikan pendaftaran objek jaminan fidusia yang akan dijadikan jaminan dari kasus yang terjadi objek jaminan yang sudah disertifikatkan masih banyak ketimpangan karena objeknya ternyata bukan milik dari orang yang menjaminkan akan tetapi objek jaminan tersebut milik orang lain, misalnya gadai mobil kendaraan dan lain-lain (Rustam, 2017).

Seiring guna melindungi salah satu pihak yang dirugikan maka harus diadakannya kebenaran secara objektif dalam mendaftarkan objek yang dijaminkan untuk didaftarkan oleh lembaga jaminan fidusia. Sehingga penelitian ini dimaksudkan untuk melihat sejauh mana notaris memperhatikan pendaftaran objek jaminan fidusia yang akan dijadikan jaminan, karena dalam berbagai kasus yang terjadi objek jaminan yang sudah disertifikatkan masih banyak ketimpangan karena objeknya ternyata bukan milik dari orang yang menjaminkan akan tetapi objek jaminan tersebut milik orang lain, kendaraan dan lain-lain. 
Pengertian Notaris menurut Pasal 1 ayat (1) Undang-undang Jabatan Notaris Nomor (UUJN) 30 Tahun 2004 jo Undang-Undang No. 2 Tahun 2014, yaitu "Notaris adalah pejabat umum yang berwenang untuk membuat akta autentik dan kewenangan lainnya sebagaimana yang dimaksud dalam undang-undang ini” (Wiradiredja, 2016). Pendaftaran jaminan fidusia dibutuhkannya akta jaminan fidusia, akta tersebut dapat dibuat dibawah tangan jika para pihak setuju dan mengakui telah dibuatnya akta tersebut walaupun tidak dibuat dihadapan notaris demi mengurangi beban biaya kepada konsumen serta mencari kemudahan. Tetapi, telah dikatakan dengan tegas menurut Pasal 5 UndangUndang Nomor 42 Tahun 1999 tentang Jaminan Fidusia yaitu: "Pembebanan Benda dengan Jaminan Fidusia dibuat dengan akta notaris dalam bahasa Indonesia dan merupakan akta Jaminan Fidusia". Hukum Dan HAM oleh notaris yang membuat akta jaminan fidusia tersebut (Anshori, 2009).

Pendaftaran jaminan fidusia dibutuhkannya akta jaminan fidusia, akta tersebut dapat dibuat dibawah tangan jika para pihak setuju dan mengakui telah dibuatnya akta tersebut walaupun tidak dibuat dihadapan notaris demi mengurangi beban biaya kepada konsumen serta mencari kemudahan. Tetapi, telah dikatakan dengan tegas menurut Pasal 5 Undang-Undang Nomor 42 Tahun 1999 tentang Jaminan Fidusia yaitu: "Pembebanan Benda dengan Jaminan Fidusia dibuat dengan akta notaris dalam bahasa Indonesia dan merupakan akta Jaminan Fidusia" (Nasution, 2019).

Proses pendaftaran akta tentang wajib daftar terhadap akta perjanjian jaminan fidusia secara online bagi perusahaan pembiayaan yang melakukan pembiayaan konsumen untuk kendaraan bermotor termuat dalam Pasal 1 Peraturan Menteri Keuangan (PMK) No. 130/PMK.010/2012, yang menyebutkan, "Perusahaan Pembiayaan yang melakukan pembiayaan konsumen untuk kendaraan bermotor dengan pembebanan jaminan fidusia wajib mendaftarkan jaminan fidusia dimaksud pada Kantor Pendaftaran Fidusia, sesuai undang-undang yang mengatur mengenai jaminan fidusia" (Nusantara, 2019).

Keluarnya peraturan ini, maka seluruh perusahaan pembiayaan harus mendaftarkan fidusia untuk setiap transaksi pembiayaannya. Terbitnya Permenkumham Nomor 9 Tahun 2013 tentang pendaftaran akta perjanjian jaminan fidusia secara online pada prinsipnya memudahkan notaris dalam melakukan pendaftaran akta perjanjian jaminan fidusia karena menggunakan sistem online sehingga dalam hitungan menit sertifikat jaminan fidusia sudah dapat di print-out melalui perangkat komputer yang dimiliki oleh notaris tersebut (Andasasmita, 1983).

Menurut (Marzuki, 2017) mengenai teori kepastian hukum menyatakan bahwa: "Teori kepastian hukum mempunyai dua pengertian yaitu pertama adanya aturan yang bersifat umum untuk membuat individu mengetahui perbuatan apa yang boleh dan tidak boleh dilakukan, dan kedua berupa keamanan hukum bagi individu dari kesewenangan pemerintah karena dengan adanya aturan hukum yang bersifat umum itu dapat mengetahui apa saja yang boleh dibebankan atau dilakukan oleh negara terhadap individu. Kepastian hukum bukan hanya pasal-pasal dalam undang-undang melainkan 
juga adanya konsistensinya dalam putusan hakim antara putusan hakim yang satu dengan putusan hakim yang lainnya untuk kasus yang serupa yang telah diputuskan.

Menurut Kamus Besar Bahasa Indonesia (KBBI) tanggung jawab adalah kewajiban menanggung segala sesuatu yang apabila terjadi apa-apa boleh dituntut, dipersalahkan, dan diperkarakan. Menurut hukum tanggung jawab adalah suatu akibat atas konsekuensi kebebasan seorang tentang perbuatannya yang berkaitan dengan etika atau moral dalam melakukan suatu perbuatan. Tanggung jawab secara etimologi adalah kewajiban terhadap segala sesuatunya atau fungsi menerima pembenaran sebagai akibat tindakan sendiri atau orang lain. Pertanggungjawaban adalah dasar kesadaran manusia akan tingkah laku atau perbuatan yang disengaja ataupun yang tidak disengaja, sehingga konsep pertanggung jawaban ini apabila dikaitkan dengan profesi notaris, maka notaris dapat dipertanggung jawabkan atas kesalahan dan kelalaiannya dalam pelaksanaan tugas dan jabatannya (Halim, 2005). Notaris tidak bertanggung jawab atas isi akta yang dibuat di hadapannya, melainkan notaris hanya bertanggung jawab terhadap bentuk formal akta otentik sebagaimana yang ditetapkan oleh Undang-undang Jabatan Notaris.

Berdasarkan uraian diatas dapat diambil pengertian bahwa kepastian hukum mempunyai dua pengertian yaitu kepastian hukum yang bersifat umum dan yang kedua kepastian hukum berupa keamanan hukum bagi individu. Oleh karenanya kepastian haruslah mengandung prinsip kepastian dan menjamin keamanan bagi setiap individu yang tumbuh di masyarakat. Manfaat dari penelitian ini terbagi 2 (dua) cara maksudnya adalah:

1. Secara teoritis. Hasil penelitian ini diharapkan dapat memberikan sumbangan pemikiran terhadap akademisi, pengemban disiplin ilmu hukum bidang hukum jaminan kebendaan pada umumnya dan hukum jaminan fidusia pada khususnya terutama tentang kepastian hukum dan tanggung jawab notaris terhadap kerugian para pihak dalam pendaftaran fidusia online.

2. Secara Praktis. Mengharapkan hasil penelitian ini dapat diserap dan dimanfaatkan oleh pelaku bisnis maupun pelaksanaan penegakan hukum bidang hukum jaminan kebendaan pada umumnya dan jaminan fidusia pada khususnya, terutama dalam hal pembebanan jaminan fidusia secara online yang diberikan oleh debitur kepada kreditur sebagai jaminan utamanya.

Penelitian ini bertujuan untuk mengkaji bahwa pendaftaran fidusia secara online dapat memberikan jaminan kepastian hukum bagi para pihak dalam hal mencegah terjadinya fidusia ulang. Untuk meneliti kendala yang dihadapi oleh notaris dalam pelaksanaan pendaftaran akta perjanjian jaminan fidusia setelah dilaksanakan secara online. Untuk memahami Tanggung jawab notaris terhadap kerugian yang timbul akibat pendaftaran fidusia online yang dilakukan oleh notaris.

\section{Metode Penelitian}

Metode penelitian yang digunakan dalam penelitian ini menggunakan pendekatan hukum normatif, dimana pendekatan terhadap permasalahan dilakukan dengan mengkaji ketentuan peraturan perundang-undangan yang berlaku dalam bidang kenotariatan pada 
umumnya dan hukum pembuatan akta notaris pada khususnya, dimana dalam pembuatan akta jaminan fidusia dan pendaftarannya secara online harus memenuhi ketentuan peraturan perundang-undangan yang berlaku dalam hal ini adalah Undang-Undang No. 42 Tahun 1999 tentang Jaminan Fidusia, UUJN No. 30 Tahun 2004 sebagaimana telah diubah dengan UUJN No. 2 Tahun 2014, Permenkumham No.9 Tahun 2013 tentang Pemberlakuan Pendaftaran akta jaminan fidusia secara online.

Alat pengumpulan data yang digunakan adalah penelitian kepustakaan (library research), studi dokumen untuk memperoleh data sekunder, dengan membaca, mempelajari, meneliti, mengidentifikasi dan menganalisis data primer yakni peraturan perundang-undangan yang mengatur tentang hukum kenotariatan yang termuat dalam Undang-Undang No. 42 Tahun 1999 tentang Jaminan Fidusia, UUJN No. 30 Tahun 2004 sebagaimana telah diubah dengan UUJN No. 2 Tahun 2014, Permenkumham No.9 Tahun 2013 tentang Pemberlakuan Pendaftaran akta jaminan fidusia secara online.

Sebelum dilakukan analisis, terlebih dahulu dilakukan pemeriksaan dan evaluasi terhadap semua data yang dikumpulkan. Setelah itu keseluruhan data tersebut akan dianalisis dan disistematisasikan secara kualitatif. Metode kualitatif merupakan metode penelitian yang digunakan untuk menyelidiki, menemukan, menggambarkan dan menjelaskan kualitas atau keistimewaan dari suatu penelitian, untuk memperoleh jawaban yang benar mengenai permasalahan pelaksanaan pembuatan akta jaminan fidusia oleh notaris dan juga pendaftarannya secara online, dimana didalam pelaksanaan pendaftarannya akta jaminan fidusia tersebut harus dilakukan secara cermat,seksama dan teliti oleh notaris agar tidak terjadi kesalahan yang dapat menimbulkan kerugian bagi pihak kreditur, sehingga dapat ditarik suatu kesimpulan yang tepat dengan metode deduktif, yaitu melakukan penarikan kesimpulan, diawali dari hal-hal yang bersifat umum untuk kemudian ditarik kesimpulan yang bersifat khusus, sebagai jawaban yang benar dalam pembahasan permasalahan yang terdapat pada penelitian ini.

\section{Hasil dan Pembahasan}

\section{A. Faktor Pendukung Dan Penghambat Dalam Proses Pendaftaran Fidusia Online}

1. Faktor Pendukung Fidusia online Direktorat Jenderal Administrasi Hukum Umum (AHU) dalam memberikan terobosan baru terhadap pelayanan public kepada masyarakat kini dan akan datang demi Indonesia yang lebih baik dengan meluncurkan sistem pendaftaran fidusia secara online.

Diharapkan dengan diluncurkannya sistem pendaftaran Fidusia online terhadap pelayanan jasa hukum di bidang fidusia dapat berjalan dengan cepat, akurat, bebas dari pungli dan dapat mendorong laju pertumbuhan ekonomi di Indonesia untuk tercapainya kesejahteraan masyarakat. Di samping itu dengan pendaftaran jaminan fidusia online akan meningkatkan pendapatan negara dari sektor Penerimaan Negara Bukan Pajak (PNBP).

Notaris yang berkarakter seolah olah di satu sisi sebagai "Pejabat Umum" namun di sisi lain juga tampil terlihat sebagai seorang "profesional" yang harus benar-benar menghayati, memahami dan mengamalkan Undang-Undang Jabatan 
Notaris dan Kode Etik Notaris serta hukum dan perundang-undangan yang berlaku. Bilamana seorang notaris, maka sebagai seorang profesional harus memenuhi persyaratan:

a. Kemampuan dan keahlian yang memadai (knowledge and skill).

b. Berpendidikan baik (well educated).

c. Rasa tanggung jawab sosial yang tinggi (high standard of sense of social responsibility).

d. Rasa kesejawatan yang kuat (sense of strong corporateness in the relationship with collagues).

e. Taat pada Kode Etik dan dan kewajiban moral.

Notaris dalam menjalankan tugasnya terutama saat membuat sertifikat harus secara profesional yang sesuai dengan aturan-aturan hukum yang sedang berlaku, karena itu sangat pentingnya objek yang dibuat oleh notaris, maka para notaris harus dapat meminimalisasi kesalahan-kesalahan ketika dalam menjalankan tugasnya dalam mendaftarkan jaminan tersebut.

Notaris juga harus dapat menghindari hal-hal yang mengandung unsur Duty, Breach of duty, Damage and causation, yang dapat mencerminkan kurang keterampilan, kurang pengetahuan dan kurang pengalaman sehingga dapat merugikan orang lain, yang akan berakibat diterapkannya sanksi sanksi perdata, sanksi pidana dan salah sanksi administrasi serta sanksi etik. Profesi Notaris berada dibawah naungan organisasi profesi yang kredibel dan merupakan bagian dari "Civil Society" dalam menegakkan Prinsip "Good Governance".

Notaris juga merupakan sebagai seorang profesional yang akan banyak menunjang pembangunan, karenakan segala akta autentik yang dibuatnya akan menjadi suatu dasar bagi para pihak, dalam melakukan pengikatan perjanjian dalam bentuk hukum, membangun kepercayaan para pihak. Fidusia online ini memang sangat bagus diluncurkan untuk memberikan rasa keamanan, kenyamanan dan ketepatan waktu sehingga pada saat pelayanan pendaftaran jaminan fidusia dapat berjalan dengan akurat, cermat, dan cepat.

Namun seiring dengan waktu diterbitkan Fidusia online, ada hal-hal yang segera perlu dicermati oleh para notaris yang profesional akan kepastian hukum terhadap pelaksanaan tugas tugas notaris di dalam proses yang harus memegang teguh dengan prinsip kehati-hatiannya. Fidusia online akan sangat bermanfaat sistemnya, namun dari sisi nilai pengkajian yuridis terdapat beberapa hal, yang dapat dikritisi supaya dapat memberikan kepastian hukum bagi para pihak. Berdasarkan dengan pendapat dari seorang notaris, ada banyak kelebihan dari sistem fidusia online saat ini adalah sebagai berikut:

a. Lebih cepat dan praktis melakukan pendaftarannya.

b. Lebih terang dan jelas tata cara pembayaran biaya pendaftarannya.

c. Dapat dibuatkan pendaftaran objek fidusia di kantor notaris, sehingga mampu mengakomodasi sistem pendaftaran ke daerah-daerah pedesaan atau perkampungan. 
d. Menuntutnya notaris supaya lebih berhati-hati akan menjalankan tugas dan fungsinya dalam praktek pendaftaran sehari-hari.

\section{B. Faktor Penghambat Dalam Fidusia Online}

Bilamana dengan adanya faktor faktor penunjang, dalam setiap sistem baru pastinya akan dapat menimbulkan faktor-faktor yang dapat menghambat. Tidak memungkinkan sebuah sistem yang diluncurkan selalu dapat didukung dengan baik oleh masyarakat setempat. Pasti ada hal-hal yang menjadi pro dan kontra dalam penerimaan di masyarakat. Hal tersebut juga merupakan suatu perihal yang wajar didalam sebuah proses untuk menuju kebaikan sistem supaya dapat bekerja lebih baik juga harus didukung oleh banyak faktor disekitarnya.

Keadaan yang sebelumnya pendaftaran jaminan fidusia secara manual, tetapi sekarang telah berkembang menjadi praktis, efisien karena dapat dilaksanakan dengan secara online. Berdasarkan dari surat yang telah diedarkan dari Direktorat Jenderal AHU tertanggal 5 Maret 2013 Nomor 06.OT.03.01. pada tahun 2013 yang menjadi suatu dasar diluncurkannya regulasi baru ini. Fidusia online yang baru berusia setahun ini setelah diluncurkan oleh Kemenkumham membuat proses untuk pendaftaran jaminan fidusia menjadi mudah karena menurut data yang di survey atau tertampung pendaftarannya jika dilakukan secara manual akan terlalu banyak dan menyita waktu yang cukup lama. Masyarakat tetap dapat menggunakan jasa notaris untuk dapat tetap membantu di Tahun 1999 banyak mengalami kendala karena kelemahan kelemahannya antara lain:

a. Tidak diatur jangka waktu pendaftaran akta jaminan fidusia.

b. Rawan akan terjadi fidusia ulang yang berujung dengan berpotensi konflik, karena tidak ada aturan yang jelas untuk jangka waktu pendaftarannya.

c. Tidak ada sanksi atau hukuman yang tegas terhadap pelanggaran pengikatan jaminan fidusia yang tidak dilakukan secara notariil.

d. Tidak ada rambu larangan atas kuasa menjaminkan yang menyebabkan maraknya penggunaan kuasa, dalam menjaminkan secara di bawah tangan untuk menunda nunda dalam pendaftaran jaminan fidusia, sehingga seringkali berpotensi konflik juga, mengingat berkaitan dengan suatu keabsahan tanda tangan yang tercantum didalam kuasa tersebut, kecuali ingin dilegalisasikan oleh notaris atau dibuat dengan secara kuasa notarial. Apabila tidak ada sanksi yang jelas terhadap surat atau akta penggunaan "kuasa jual" yang jelas-jelas sangat bertentangan dengan cara-cara melakukan tindakan eksekusi sesuai dengan UU No.42 Tahun 1999 sehingga memiliki potensi tidak memberikan rasa keamanan, kenyamanan dan keadilan bagi debiturnya.

e. Tidak ada persamaan dalam penggunaan Data Base di Kantor Pendaftaran Jaminan Fidusia sehingga sangat rawan terjadi Fidusia Ulang.

Hambatan dalam permasalahan ini penulis mengkriteriakan menjadi dua golongan hambatan. Hambatan yang pertama adalah suatu yang dinilai sebagai hambatan yang telah berawal dari suatu peraturan hukum yang dapat mengatur itu sendiri yang disebutkan sebagai suatu masalah yuridis didalam penerapan sistem 
pendaftaran fidusia online. Hambatan yang kedua dinilai sebagai suatu hambatan yang berasal dari luar peraturan hukum fidusia, yang datangnya dari dalam masyarakat itu sendiri yang dapat disebutkan sebagai sebuah hambatan non yuridis.

1. Hambatan secara Yuridis

Dengan tata cara diberlakukannya pendaftaran jaminan Fidusia online, ada beberapa perihal yang dirasakan kurang tepat atau kurang pas dengan Pasal-Pasal UU No.42 Tahun 1999 antara lain dengan ketentuan sebagai berikut ini:

a. Pasal 12: Pendaftaran jaminan fidusia dilakukan pada Kantor Pendaftaran Fidusia. Kenyataanya Pendaftaran kerap kali dilakukan di Kantor Notaris masing masing secara online system (Asuan, 2018).

b. Pasal 13 Ayat (1) Permohonan pendaftaran jaminan fidusia dilakukan oleh Penerima Fidusia, kuasa atau wakilnya dengan melampirkan pernyataan pendaftaran jaminan fidusia. Kenyataanya dilapangan dengan pendaftaran fidusia online, tidak ada lagi penyerahan data fisik objeknya ke kantor pendaftaran jaminan fidusia lagi (Harahap, 2017).

c. Pasal 13 Ayat (2) Pernyataan pendaftaran fidusia sebagaimana dimaksud dengan ayat (1) memuat (Nugraha, 2019):

1) identitas pihak Pemberi dan Penerima Fidusia.

2) tanggal, nomor akta jaminan fidusia, nama, tempat kedudukan notaris yang membuat akta jaminan fidusia.

3) data perjanjian pokok yang dijamin fidusia.

4) uraian mengenai benda yang menjadi objek jaminan fidusia.

5) nilai penjaminan; dan

6) nilai benda yang menjadi objek jaminan fidusia. dalam pendaftaran fidusia on line, tidak ada fasilitas kolom untuk memasukkan data mengenai uraian benda yang menjadi objek jaminan fidusia, hanya sesuai akta notaris.

d. Pasal 14 ayat (2): Sertifikat Jaminan Fidusia yang merupakan salinan dari Buku Daftar Fidusia memuat catatan tentang hal-hal sebagaimana dimaksud dalam Pasal 13 ayat (2). Faktanya dengan berlakunya pada jaminan Fidusia on line, Sertifikat Jaminan Fidusia tidak memberi bukti dengan kenyataan sebagaimana dengan Pasal 13 ayat (2) tersebut diatas (Koraag, 2016).

Hanya "sesuai akta notaris" Pasal 16 Ayat (1) Apabila terjadi perubahan bersangkutan dengan hal-hal yang tertera di dalam Sertifikat Jaminan Fidusia tersebut dalam Pasal 14 (2) (Yani \& Widjaja, 2003), Pihak Penerima Jaminan Fidusia wajib melakukan pengajuan dari permohonan untuk pendaftaran atas perubahan tersebut di Kantor Pendaftaran Fidusia. Bilamana di dalam fidusia on line, ada permasalahan dalam perubahan yang belum terakomodasi secara on line, maka akan tetap didaftarkan secara manual (Olii, 2017).

Pasal 25 Ayat (3) Penerima Fidusia memberitahukan kepada Kantor Pendaftaran Fidusia mengenai hapusnya jaminan fidusia sebagaimana dalam ayat (1) dengan melampirkan pernyataan mengenai hapusnya utang, pelepasan hak, atau musnahnya Benda yang menjadi objek jaminan fidusia tersebut. 
Kenyataanya saat ini problema roya baru-baru ini sudah diakomodasi dijalankan secara manual kembali, dan mengingat belum ada terakomodasi didalam pendaftaran jaminan Fidusia online (Notaris, Ketiga, \& Aditama, 2009).

2. Hambatan Secara Non Yuridis

Ada beberapa perihal yang perlu diperhatikan secara teliti dalam pendaftaran sistem Fidusia online, antara lain (Sasea, 2020):

a. Tampilan Formulir Pendaftaran memungkinkan pemohon pendaftaran tidak hanya notaris namun ada juga dalam pengajuan untuk fasilitas pemohon yang terdapat Perseorangan atau perusahaan.

b. Tampilan identitas biodata untuk perseorangan.

c. Tampilan identitas biodata penerima fidusia (untuk Perusahaan) terdapat pula isian NPWP/No. SK. Dalam pembuatan akta jaminan fidusia, dapat meminta berkas lengkap termasuk NPWP dan No. SK yang mana, harus akan dicantumkan. (Ketegasan No. SK yang mana yang akan dicantumkan).

d. Pada tampilan isi data merupakan perjanjian pokok maka Tampilan apakah yang bisa untuk melakukan penginputan data perjanjian yang juga berupa pertanggungan renteng atau Kredit Sindikasi atau joint collateral dan lain-lain. Apabila berdasarkan dari perjanjian pokok yang terdiri dari beberapa fasilitas kredit

\section{Kesimpulan}

Peneliti telah sampai pada akhir penutup yang menjadi semua paparan merupakan intisari dari hasil penelitian tesis ini, yang merupakan uraian di bab terakhir berisikan saran dan konklusi. Adapun kesimpulan kesimpulan yang peneliti sampaikan bawa berdasarkan dari kewenangan notaris menjalankan seluruh pendaftaran jaminan fidusia dengan secara online tertera pada Pasal 13 ayat (1) Undang-Undang Jaminan Fidusia dan Pasal 2 PP No. 21 Tahun 2015 mengatakan dengan seksama bahwa dalam permohonan pendaftaran Jaminan Fidusia, permohonan perubahan sertifikat Jaminan Fidusia, permohonan perbaikan sertifikat Jaminan Fidusia, dan pemberitahuan penghapusan sertifikat Jaminan Fidusia yang telah diajukan oleh pihak penerima Fidusia, kuasa atau wakilnya kepada Menteri Hukum dan Hak Asasi Manusia secara elektronik. Dengan demikian maka tertera didalam Pasal 13 ayat (1) UUJF yang telah mengatur bahwa pengajuan dari pendaftaran jaminan fidusia telah dilakukan oleh penerima fidusia, kuasa atau wakilnya (para pihak) terkait. Dengan berdasarkan dari berkaitan dengan pasal tersebut yang dapat mendaftarkan jaminan fidusia adalah kreditor yang merupakan sebagai penerima fidusia dan dapat memungkinkan pula kreditor memberikan kuasanya atau diwakilkan kepada notaris untuk mendaftarkan jaminan fidusia tersebut secara online.

Notaris di dalam menjalankan pendaftaran jaminan fidusia yang berdasarkan pada Pasal 13 ayat (1) Undang-undang Jaminan Fidusia tercantum akan tanggung jawab padanya, sebagai pihak dari penerima kuasa dalam menjalani pendaftaran fidusia, maka dari itu notaris wajib melakukan pendaftaran fidusia tersebut, harus dengan hati hati, teliti 
dan cermat agar tidak terjadi kesalahan dalam melakukan pendaftaran. Salah satu bentuk kesalahan notaris, dimana notaris dalam melakukan pendaftaran fidusia secara online dapat pula dalam bentuk kesalahan administratif maupun kesalahan dalam bentuk perdata atau privat maka dengan demikian juga akan menjadi tanggung jawab notaris, juga akan meliputi pertanggungjawaban administratif dan pertanggungjawaban privat atau perdata. Jika terjadi suatu kesalahan administratif, maka tanggung jawab notaris akan hanya sebatas untuk merubah, mengedit dan memperbaiki data jaminan fidusia tersebut, yang kemudian akan diajukan pendaftarannya kembali, sedangkan dalam tanggung jawab perdata yaitu notaris dapat dituntut di pengadilan atas dasar terjadinya suatu wanprestasi ataupun perbuatan yang melanggar atau melawan hukum sehingga menimbulkan kerugian pada para pihak yang mengajukan pendaftaran jaminan fidusia tersebut.

Peraturan hukum kedepan yang perlu dijabarkan yang setidaknya akan mengandung prinsip-prinsip hukum, yaitu prinsip kepastian hukum, prinsip publisitas hukum dan prinsip preferen atau hak untuk didahulukan, khusus untuk perihal prinsip kepastian hukum yang akan mengarah pada prinsip kehati hatian atau prinsip prudential di dalam melakukan pendaftaran fidusia secara online yang dijalankan oleh notaris belum dapat ditemukan, baik didalam UUJF maupun di dalam UUJN. Sedangkan dalam menjalankan pengaturan pendaftaran fidusia online hanya diatur sebagai suatu syarat formilnya saja, semisal melengkapi data dari penerima fidusia, uraian dari objek jaminan, jumlah nilai penjaminan, membuat tanggal dan nilai benda yang akan menjadi objek dari jaminan fidusia sebagaimana yang telah diatur dalam Pasal 5 ayat (1) dan Pasal 6 UUJF. 
Tanggung Jawab Notaris dan Kepastian Hukum bagi Kreditur Akibat Lalai dalam Pendaftaran Fidusia Online

\section{BIBLIOGRAFI}

Andasasmita, Komar. (1983). Notaris Selayang Pandang. Bandung: Alumni. Google Scholar

Anshori, Abdul Ghofur. (2009). Lembaga Kenotariatan Indonesia: Perspektif Hukum Dan Etika. Uii Press. Google Scholar

Asuan, Asuan. (2018). Penyelesaian Debitur Wanprestasi Dalam Perjanjian Kredit Jaminan Fidusia Menurut Undang-Undang No. 42 Tahun 1999 Tentang Jaminan Fidusia. Solusi, 16(3), 253-265. Google Scholar

Halim, A. Ridwan. (2005). Pengantar Ilmu Hukum Dalam Tanya Jawab. Google Scholar

Harahap, M. Yadi. (2017). Pengaturan Lembaga Jaminan Fidusia Di Indonesia Perspektif Undang-Undang No. 42 Tahun 1999 Tentang Jaminan Fidusia. Al-Usrah, 5(1). Google Scholar

Koraag, Jeaflin. (2016). Pengaturan Tentang Jaminan Fidusia Berdasarkan UndangUndang No. 42 Tahun 1999 Tentang Jaminan Fidusia. Lex Privatum, 4(3). Google Scholar

Marzuki, Mahmud. (2017). Penelitian Hukum: Edisi Revisi. Prenada Media. Google Scholar

Nasution, Mora Bumi. (2019). Tanggung Jawab Notaris Dalam Pelaksanaan Pendaftaran Akta Jaminan Fidusia Secara Online Terhadap Penerima Sertifikat Jaminan Fidusia. Google Scholar

Notaris, Jabatan, Ketiga, Cetakan, \& Aditama, Refika. (2009). Sanksi Perdata Dan Administrasi Terhadap Notaris Sebagai Pejabat Publik, Pt. Refika Aditama, Bandung. Google Scholar

Nugraha, Andi Wahyu Agung. (2019). Prinsip-Prinsip Hukum Jaminan Fidusia Dalam Perspektif Undang-Undang Nomor 42 Tahun 1999 Tentang Jaminan Fidusia. Lex Privatum, 6(10). Google Scholar

Nusantara, Ni Putu Theresa Putri. (2019). Eksekusi Dan Pendaftaran Objek Jaminan Fidusia Berdasarkan Undang-Undang Nomor 42 Tahun 1999 Tentang Jaminan Fidusia. Jurnal Fakultas Hukum Universitas Udayana, 2. Google Scholar

Octavianus, Aldo. (2018). Hak Debitur Atas Objek Jaminan Fidusia Sebagai Hak Kebendaan Menurut Undang-Undang Nomor 42 Tahun 1999 Tentang Jaminan Fidusia. Lex Crimen, 6(10). Google Scholar

Olii, Restu Juniar P. (2017). Akibat Hukum Eksesekusi Objek Jaminan Fidusia Yang Tidak Didaftarkan Menurut Uu No. 42 Tahun 1999 Tentang Jaminan Fidusia. Lex Privatum, 5(4). Google Scholar 
Lirianna Nurtanio Jonatan, Gunawan Djajaputra

Rustam, Riky. (2017). Hukum Jaminan. Google Scholar

Sasea, Enny Martha. (2020). Upaya Perlawanan Lelang Eksekusi Hak Tanggungan: Perspektif Kreditor. Amanna Gappa, 87-100. Google Scholar

Wiradiredja, Hilda Sophia. (2016). Pertanggungjawaban Pidana Notaris Dalam Pembuatan Akta Yang Didasarkan Pada Keterangan Palsu Dihubungkan Dengan Undang-Undang Nomor 30 Tahun 2004 Tentang Jabatan Notaris Jo UndangUndang Nomor 2 Tahun 2014 Dan Kuhp. Jurnal Wawasan Yuridika, 32(1), 58-81. Google Scholar

Yani, Ahmad, \& Widjaja, Gunawan. (2003). Jaminan Fidusia, Pt. Raja Grafindo Persada, Jakarta. Google Scholar

Copyright holder:

Lirianna Nurtanio Jonatan, Gunawan Djajaputra (2021)

First publication right:

Syntax Literate: Jurnal Ilmiah Indonesia

This article is licensed under:

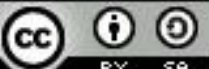

